\author{
Jan N. Schieveld \\ Marian Staal \\ Laurens Voogd \\ Jeanne Fincken \\ Gijs Vos \\ Jim van Os
}

\section{Refractory agitation as a marker for pediatric delirium in very young infants at a pediatric intensive care unit}

Accepted: 8 June 2010

Published online: 6 August 2010

(C) The Author(s) 2010. This article is published with open access at

Springerlink.com

Dear Editor,

Refractory agitation in infants is frequently met at the pediatric intensive care unit (PICU) [1]. Finding the right sedative to remedy this can be challenging, particularly as previous research has shown that agitation in critically ill children may also be a marker for pediatric delirium (PD) [1].

Over the last 2 years, four very young critically ill infants (two girls, two boys; age range $7-14$ months; mechanically ventilated and receiving analgosedation according to international guidelines) presented with refractory agitation. Description of the context and diagnostic approach in our unit can be found in previous publications [1]. Two of the four children received alimemazine in order to remedy agitation that was present in spite of adequate analgosedation; however, agitation worsened. In the two other infants, analgosedative medication was being tapered off slowly when the children developed agitation; despite reinstatement of analgosedative medication at its original dose or even higher, agitation continued.

Although the Diagnostic and Statistical Manual, fourth edition, text revision (DSM-IV-TR) states that cognitive change must be observed in order to diagnose delirium, it has been argued that refractory agitation-as observed in these four infants, after exclusion of other logical explanations-may be more usefully considered as an expression of PD $[1,2]$, which requires a different approach.

Delirium superimposed on withdrawal may present as an excess in the number, intensity, duration, and/ or responsiveness of the symptoms normally associated with withdrawal [2]. In the first two children, sedative medication may have induced PD through anticholinergic mechanisms (see below). In the other two children, PD was superimposed on withdrawal symptoms, as evidenced by nonresponse to reinstatement of the original sedative.

A recent consensus guideline on sedation and analgesia in critically ill children suggested that promethazine or alimemazine (trimeprazine), both H1-receptor antagonists, may be considered for sedation [3]. However, these medications are characterized not only by sedation but also by strong anticholinergic side-effects, which may provoke agitation rather than sedation in children, given that cholinergic and dopaminergic neurotransmission is linked to delirium pathophysiology through, respectively, hypocholinergic and/or hyperdopaminergic states [4]. Thus, H1-antagonists with their strong anticholinergic and weak D2-blocking effects may kindle and aggravate refractory agitation. Haloperidol, however, with its weak anticholinergic and strong D2-blocking effects, may constitute a more effective treatment $[5,6]$.

Haloperidol is a well-studied drug with few side-effects and has been successfully used for agitation in young children [5, 6]. Haloperidol and alimemazine both have low risks of cardiac side-effects-alimemazine may carry a higher riskand rarely may induce malignant neuroleptic syndrome. The four children were successfully treated with haloperidol intravenously according to a minimal treatment schedule (Table 1).

An empirical approach of steadily titrating and close monitoring is advocated in order to find the right dosage, maneuvering between clinical response and side-effects. One patient developed an intermittent oculogyric crisis that was successfully treated with $50 \mu \mathrm{g} / \mathrm{kg}$ biperiden i.v.

We conclude that refractory agitation at the PICU may be a marker of underlying PD, and that haloperidol rather than an H1-receptor antagonist may give satisfactory results.

Table 1 Minimal intravenous haloperidol dosage scheme for delirium in pediatric patients

\begin{tabular}{llll}
\hline $\begin{array}{l}\text { Age } \\
\text { (years) }\end{array}$ & $\begin{array}{l}\text { Weight } \\
(\mathrm{kg})\end{array}$ & $\begin{array}{l}\text { Loading dose } \\
(\mathrm{mg} \mathrm{IV})\end{array}$ & $\begin{array}{l}\text { Haloperidol starting } \\
\text { dosage }(\mathrm{mg} / \mathrm{kg} / 24 \mathrm{~h} \text { i.v. }\end{array}$ \\
\hline $0-1$ & $3.5-10$ & 0.05 & 0.01 \\
$1-3$ & $10-15$ & 0.15 & 0.025 \\
$3-18$ & $>15$ & 0.25 & 0.05 \\
\hline
\end{tabular}

Maximal haloperidol dosage in adults is approximately $5 \mathrm{mg} / 24 \mathrm{~h}$ i.v. 


\section{Conflict of interest None.}

Open Access This article is distributed under the terms of the Creative Commons Attribution Noncommercial License which permits any noncommercial use, distribution, and reproduction in any medium, provided the original author(s) and source are credited.

\section{References}

1. Schieveld JNM, Leroy PL, van Os J, Nicolai J, Vos GD, Leentjens AF (2007) Pediatric delirium in critical illness: phenomenology, clinical correlates and treatment response in 40 cases in the pediatric intensive care unit. Intensive Care Med 33:1033-1040. doi:10.1007/s00134-007-0637-8

2. American Psychiatric Association (2000) Diagnostic and statistical manual of mental disorders, DSM-IV-TR.

American Psychiatric Association, Washington, DC, p 208

3. Playfor S, Jenkins I, Boyles C, Choonara I, Davies G, Haywood T et al (2006) Consensus guidelines on sedation and analgesia in critically ill children. Intensive Care Med 32:1125-1136. doi:10.1007/s00134-006-0190-x

4. Trzepacz PT, Meagher DJ (2005) Delirium. In: Levenson JL (ed) The American Psychiatric Publishing textbook of psychosomatic medicine. American Psychiatric, Washington, DC, pp 91-130
5. Brown RL, Henke A, Greenhalgh DG, Warden GD (1996) The use of haloperidol in the agitated, critically ill pediatric patient with burns. J Burn Care Rehabil 17:34-38

6. Harrison AM, Lugo RA, Lee WE, Appachi E, Bourdakos D, Davis SJ, McHugh MJ, Weise KL (2002) The use of haloperidol in agitated critically ill children. Clin Pediatr (Phila) 41:51-54. doi:0.1177/000992280204100111

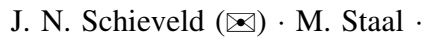

L. Voogd · J. Fincken

Division of Child and Adolescent

Psychiatry and Psychology,

Department of Psychiatry and Psychology,

European Graduate School of Neuroscience,

SEARCH, Maastricht University Medical

Centre, PO Box 5800,

6202 AZ Maastricht, The Netherlands

e-mail: jan.schieveld@mumc.nl

Tel.: +31-43-3877499

Fax: +31-43-3875444
G. Vos

Division of Pediatric Intensive Care

Medicine, Department of Pediatrics,

Maastricht University Medical Centre,

PO Box 5800, 6202 AZ Maastricht,

The Netherlands

J. van Os

Department of Psychiatry and Psychology,

European Graduate School of Neuroscience, SEARCH, Maastricht University Medical Centre, PO Box 616,

6202 AZ Maastricht, The Netherlands 